\title{
Germ Cell, Stem Cell, and Genomic Modification in Birds
}

\section{Tae Sub Park ${ }^{1,2}$, Hyung Chul Lee ${ }^{1}$, Deivendran Rengaraj ${ }^{1}$ and Jae Yong Han ${ }^{1 *}$ \\ ${ }^{1}$ Department of Agricultural Biotechnology, College of Agriculture and Life Sciences, Seoul National University, Seoul 151-921, Korea}

${ }^{2}$ Institute of Green-Bio Science and Technology, Seoul National University, Pyeongchang-gun, Gangwon-do, 232-916, Korea

\begin{abstract}
Germ cells are the only type of cell that can transmit all genomic information to the next generation. Such cells have unique characteristics, being not only germline-competent but also serving as stem cells. In Caenorhabditis elegans and Drosophila, germ cell lineages are predetermined. In contrast, in mammals, primordial germ cells, which are precursors of germ cells, are induced from multipotent epiblasts via extra-embryonic signaling. In avian species, however, the means by which germ cells are defined remain to be elucidated. Manipulation of germ cells is valuable in studies on germline development and in production of valuable cell lines. In birds, which lack germline-competent stem cells, genomic modulation of germ cells might serve to generate genetically modified poultry for both commercial applications and basic research.
\end{abstract}

Keywords: Germ cells; Periodic acid-Schiff (PAS); SSEA-1; HH 4; Magnetic-activated cell sorting

\section{Avian Primordial Germ Cells}

\section{Primordial germ cell biology and manipulation}

Primordial germ cells (PGCs), the precursors of germ cells, form during early embryonic development. To date, studies on the PGCs of many species have investigated specification, proliferation, and differentiation, and have created various applications using model animal systems. Avian species are optimal vertebrates in which to examine germ cell development during embryogenesis, because of their oviparity. Earlier studies on PGCs focused principally on the locations and numbers of such cells. To identify PGCs in early stage embryos, PGC-specific markers including the periodic acid-Schiff (PAS) reagent $[1,2]$ and anti-stage specific embryonic antigen-1 (SSEA-1) antibody [3], were used. During early embryonic development, chicken PGCs exhibit a unique migratory activity (toward the genital ridges) [4]. PGCs in the central zone of the area pellucida move toward and gather in the anterior region of the embryo, the germinal crescent of Hamburg and Hamilton stage $4(\mathrm{HH} 4)$. Subsequently, PGCs invade blood vessels, and migrate therein, settling in the genital ridges, where they finally differentiate into functional gametes [5]. The unique migration pathway of chicken PGCs (through the circulation) is unlike that of mammalian PGCs (which migrate through the dorsal mesentery [6]), and makes it possible to isolate, manipulate, and re-transplant such cells.

PGC isolation procedures including magnetic-activated cell sorting (MACS) and fluorescence-activated cell sorting (FACS) have been used to perform large-scale analyses of mRNA, protein, and microRNA expression in chicken PGCs [7-9]. One unique feature of PGCs is their potential to serve as stem cells. Although PGCs are unipotent, in the sense that the cells give rise to mature germ cells during life, PGCs apparently also express pluripotent markers and can in fact exhibit pluripotency, to form embryonic germ cells (EGCs) under specific culture conditions. In the mouse, PGCs can de-differentiate into EGCs when cultured with a specific cocktail of growth factors including bFGF, Steel factor, and leukemia inhibitory factor (LIF) [10]. EGCs can form embryoid bodies in vitro and teratocarcinomas in vivo [11]. EGCs are also transmissible via the germline to the next generation. In the chicken, EGCs have been derived from PGCs grown in vitro [12]. As in the mouse, chicken EGCs can contribute to germline chimeras exhibiting characteristics similar to those of murine embryonic stem cells [13].

To date, long-term in vitro culture systems for avian PGCs have been established only for the chicken, rendering it possible to generate germline chimeras exhibiting efficient germline transmission. Upon addition of basic fibroblast growth factor (bFGF) to culture media, chicken PGCs can proliferate in vitro and induce germline chimeras when transplanted into recipients [14]. In addition, transgenic chickens have been produced using in vitro-cultured and genetically modified PGCs [15-17]. Germ cell manipulation techniques have been extended to aid in the restoration of endangered avian species. Interspecies germline chimeras have been successfully produced by injection of PGCs of various avian species into recipient chicken embryos or vice versa [18-22]. Interestingly, PGCs from different avian species can successfully migrate into genital ridges and proliferate in differentiated gonads when reintroduced to the recipients [18,21]. Thus, the endangered birds could be conserved and restored through the interspecies germline chimera production system. Nevertheless, there are still several practical obstacles to be solved for applying to various avian species; in vitro PGC culture technique optimization for different avian species, differences in egg size and sexual maturation periods between a donor and a recipient, and low efficiency of the repopulation of donor PGCs in recipient gonads [22].

\section{Avian germ cell specification}

As germ cells play crucial roles in delivering genetic material to the offspring, development of such cells is strictly regulated from the initial stages of growth. In terms of germ cell specification, two different mechanisms have been adopted by various species; these are the pre-formation and induction modes [23]. In species using

*Corresponding author: Jae Yong Han, Department of Agricultural Biotechnology, College of Agriculture and Life Sciences, Seoul National University, Seoul 151-921, Korea, Tel: +82 2880 4810; Fax: +82 2874 4811; E-mail: jaehan@snu.ac.kr

Received March 25, 2014; Accepted May 01, 2014; Published May 03, 2014

Citation: Park TS, Lee HC, Rengaraj D, Han JY (2014) Germ Cell, Stem Cell, and Genomic Modification in Birds. J Stem Cell Res Ther 4: 201. doi:10.4172/21577633.1000201

Copyright: ( 2014 Park TS, et al. This is an open-access article distributed under the terms of the Creative Commons Attribution License, which permits unrestricted use, distribution, and reproduction in any medium, provided the original author and source are credited. 
the pre-formation mode, such as Caenorhabditis elegans, Drosophila melanogaster, and Xenopus laevis, a maternally inherited complex, the germplasm, plays a critical role in PGC specification. The existence of such a model has been confirmed by removal, or transplantation analysis, of germplasm [24,25]. However, induction in the mouse (one of the best-studied species) involves PGC segregation from somatic cells triggered by a series of inductive signals from neighboring tissues [26].

Germ cell specification in birds has been less studied than in other animals, principally because of a lack of reliable PGC markers. After the first identification of chicken PGCs by Swift [27], a study using chick-quail chimeras showed that avian germ cells originated from the epiblastic area [28]. Further studies supported the notion that PGCs appeared in the EGK X region, and confirmed the mode of induction in the chicken $[3,29]$. Next, the germplasm structure of the oocyte was identified, and germplasm-containing cells were observed during early cleavage stages, using an anti-chicken vasa homolog $(\mathrm{CVH})$ antibody [30]. Vasa are one of the most important proteins in the germplasm and are conserved among many species $[31,32]$. Thus, future studies should focus on the molecular mechanisms underlying germ cell specification in the chicken.

\section{Expression and Regulation of Marker Genes in Avian Germ Cells}

\section{Expression of marker genes during various developmental stages}

A number of marker genes are expressed specifically in avian germ cells during various developmental stages in order to maintain the properties/characteristic features of germ cells. Such marker genes can be classified in various ways, and include pluripotency-related genes, germline-related genes, migration-related genes, methylation-related genes, and meiosis-related genes. Avian PGCs can self-renew and differentiate into embryonic germ cells. Therefore, PGCs can express particular pluripotency-related genes, including "POU domain class 5 transcription factor 1" (POUV), "nanog homeobox" (NANOG), and "SRY (sex determining region Y)-box 2" (SOX2) [33,34]. These genes are expressed by PGCs until the cells settle in the gonads $[33,34]$, suggesting that they are required for maintenance of the pluripotency and self-capacity of PGCs until such cells differentiate into germ cells. Expression of germline-related genes can be detected in germ cells of all developmental stages. To date, several germlinerelated genes have been reported in avian species; these include the "chicken vasa homolog" (CVH), "deleted in azoospermia-like" (DAZL), and "chicken dead end homolog" (CDH) [30,35-37] genes. Immunohistochemical analysis using an anti-CVH antibody detected CVH-positive cells from the time of fertilization to formation of the adult testis/ovary [30], suggesting that $\mathrm{CVH}$ is crucial for the normal development and maintenance of germline cells. In addition, several immunological markers, including stage-specific embryonic antigens (SSEA-1, SSEA-3, and SSEA-4); epithelial membrane antigen (EMA1); integrin alpha 6; and integrin beta 1 , are selectively expressed by PGCs [38]. Notably, the cell-surface glycoprotein marker SSEA-1 is commonly used to trace and retrieve avian PGCs at different stages of embryonic development [38,39]. Avian PGCs are transported by the vascular system into developing gonads. Cell entry into, migration within, and exit from the vascular system are governed by a receptor complex composed of chemokine ( $\mathrm{C}-\mathrm{X}-\mathrm{C}$ motif) receptor 4 and the CXCR4 ligand; this complex is termed the "chemokine stromal cellderived factor 1 (SDF1)" complex. Chicken CXCR4 is expressed in
PGCs, and SDF1 was shown to be present in places in which PGCs were located after leaving blood vessels $[34,40]$.

DNA methylation is crucial in terms of embryonic development, facilitating genomic imprinting, X-chromosome inactivation, chromatin modification, and gene expression [41,42]. Also, DNA methylation is closely associated with modification of DNA-bound histones, catalyzed by histone acetyltransferases (HATs) and histone deacetylases (HDACs) [43,44]. DNA methylation involves the actions of three major enzymes; these are (cytosine-5-)-methyltransferase 1 (DNMT1), DNMT 3-alpha (DNMT3A), and DNMT3-beta (DNMT3B). DNMT1 is involved in maintenance of DNA methylation patterns, whereas DNMT3A and DNMT3B are required for establishment of new methylation patterns $[42,45]$. DNMT1 and DNMT3A are expressed ubiquitously in early stage chicken embryos. In contrast, DNMT3B expression in PGCs is strongest prior to differentiation of such cells into germ cells. After PGC differentiation, DNMT3B was detected in female germ cells until adulthood was attained [46]. Apart from the genes and proteins mentioned above, recent work by Jang et al. identified many novel genes involved in the establishment and maintenance of DNA methylation in avian PGCs [47]. Germ cells undergo mitosis and meiosis to complete gametogenesis. Avian PGCs at early embryonic stages undergo rapid mitotic proliferation to increase population numbers. After PGCs enter the bilateral gonads, the cells begin to differentiate into oogonia in females at embryonic day (E) 8.0, and prospermatogonia in males at E13.0 [35,48]. Oogonia engage in further mitosis to increase cell numbers, finally becoming arrested at meiotic prophase I as early as E15.5, until cells are selected for formation of primitive follicles $[49,50]$. In contrast, prospermatogonia become arrested at mitosis until hatching, and proliferation then resumes, along with proliferation of Sertoli cells [49-51]. Spermatogonia enter meiotic prophase only after completion of Sertoli cell proliferation, at $\sim 8$ weeks after hatching [50,51]. Identification of avian germ cells undergoing meiotic processes remains difficult; however, this can sometimes be achieved by correlating the temporal expression patterns of a premeiotic marker gene ("stimulated by retinoic acid gene 8"; STRA8) and synaptonemal complex genes (SYCPs) $[49,50]$. STRA8 was expressed at high levels from E12.5 through to the meiotic stage, whereas highlevel SYCP3 expression was noted from the onset of meiosis (E15.5) through to the meiotic stage $[49,50]$.

\section{miRNA-mediated regulation of marker genes in avian germ cells}

miRNAs (microRNAs) are families of single-stranded small noncoding RNAs present in most cells. miRNAs range from 19-25 nt in length and are usually derived from gene transcripts that fold back on themselves to form distinctive hairpin structures $[52,53]$. The numbers of identified miRNAs are $\sim 1-2 \%$ of the numbers of genes of various species [54]. miRNAs binds to complementary seed sequences at 5'UTRs (untranslated regions), or coding regions, or 3'UTRs, of mRNAs (but preferentially to $\left.3^{\prime} U T R s\right)$, to engage in post-transcriptional regulation during various cellular activities [54,55]. This post-transcriptional regulatory machinery has been investigated extensively in mammalian species during all of embryonic development, cell proliferation, apoptosis, expression of stress-resistance mechanisms, cancer development, and maintenance of pluripotency by ESCs $[52,53,56]$. miRNAs targeting avian genes can be identified using the MicroRNA Target Prediction and Functional Study Database (miRDB; http:// mirdb.org/miRDB/). This database employs the MirTarget2 algorithm to predict miRNA:mRNA pairs in the human, mouse, rat, dog, and chicken [57]. Recently, several studies have explored the expression 
levels of candidate miRNAs in avian germ cells and the testis/ovary, however, these miRNAs are potentially involved in regulation of marker genes which determine the characteristic features of germ cells. For example, Shao et al. identified 29 novel miRNAs and 140 potential miRNA loci in the chicken genome [58]. Of the identified miRNAs, several, including miR-26a, miR-143, and miR-199, were strongly expressed in the adult ovary [58]. Smith et al. found that miRNAmediated knockdown of doublesex and mab-3-related transcription factor 1 (DMRT1) expression triggered feminization of embryonic gonads in genetically male (ZZ) chicken embryos [59].

In a study by Bouhallier et al. [60], transfection of miR-34c (which is involved in control of the late steps of spermatogenesis) into a modified (CVH-overexpressing) chicken ESC line increased the expression levels of germ cell- and pluripotency-specific genes. This suggests that miR-34c enhances the germinal phenotype of cells already committed to such lineage [60]. Rengaraj et al. reported that four miRNAs (miR-15c, miR-29b, miR-383, and miR-222), (targeting the de novo methylation-related gene DNMT3B) were differentially expressed during germline development in chickens. In particular, miR-15c, miR-383, and miR-222 levels increased in male gonads during embryonic development. Further, co-transfection of various constructs with these miRNAs effectively downregulated DNMT3B, as revealed using a dual fluorescent reporter assay [46]. Employing microarray and expression analyses, Lee et al. [9] identified about 10 miRNAs (miR-92, miR-19a, miR-19b, miR-18a, miR-18b, miR-30c, miR-101, miR-128, miR-383, and miR-181*) that were highly expressed in chicken PGCs. Of these, miR-181a* played a crucial role, inhibiting somatic differentiation by silencing the homeobox A1 (HOXA1) gene, and preventing PGCs from entering meiosis by silencing the "nuclear receptor subfamily 6, group A, member 1" (NR6A1) gene [9]. Another study found that two miRNAs, miR-302b and miR-17-5p, significantly regulated the expression level of glucose phosphate isomerase (GPI), a critical enzyme of glycolysis/gluconeogenesis in germ cells. In addition, miR-302b- or miR-17-5p-mediated knockdown of GPI reduced in vitro chicken PGC proliferation [61].

\section{piRNA-mediated regulation of marker genes in avian germ cells}

piRNAs (P-element-induced wimpy testis [PIWI]-interacting RNAs) are small non-coding RNAs derived either from repetitive sequences (transposable elements) or non-repetitive sequences (protein-encoding genes). Unlike miRNAs and small interfering RNAs (siRNAs), piRNAs are synthesized via a dicer-independent pathway, and piRNAs are a little longer than miRNAs and siRNAs [62]. Transposable elements are also termed non-coding genes, or jumping genes, because they repeatedly change positions within a genome, damaging coding DNA, and ultimately compromising normal cell functioning. Thus, the principal function of transposable elementderived piRNAs is to silence transposable elements [62,63]. piRNAs are required for development and maintenance of germ cells, and play crucial roles as post-transcriptional regulators in the germ cells of different vertebrates [64]. In germ cells, piRNAs interact significantly with several germ cell-marker genes including the PIWI homolog and VASA homolog [65]. To our knowledge, little is known on how to identify piRNA classes or the post-transcriptional regulatory functions of piRNAs on avian germ cells-expressed marker genes. However, Kim et al. [66] recently described the expression patterns and functions of the CIWI and CILI, the known piRNA-interacting gene homologs of the chicken. In the cited work, both CIWI and CILI were strongly expressed in germ cells. Moreover, knockdown of CIWI and CILI using exogenous siRNAs caused a transposable element-mediated DNA double-strand breakage in such cells [66].

\section{Reprogrammable Genomic Editing in Birds}

Transgenic technology is a valuable approach toward investigation of specific gene function(s) in vivo [67]. To date, the technique has found applications in basic biology, medicine, functional genomics, and agriculture [68]. In early work, virus-mediated transfer systems were used for stable transgene delivery and development of transgenic lines. However, recently, more stable and safer non-viral gene transfer procedures using the piggyBac and Tol2 transposons, and transposases, have been established; these approaches can be applied to avian species $[16,17]$. In mouse as an animal model system, transgenic technology has been utilized for functional genomics study to examine biological role(s) of novel gene during embryo development and through in vivo analysis [68]. Particularly, this system provided the strong clue to discover regulatory network and mechanism. Promoter with tissue- or developmental stage-specific regulatory elements can induce spatiotemporal overexpression of the interested gene in specific target organ. In birds, the recently developed transposon elements advanced transgenic technology and provided the efficient production system of transgenic lines [68]. For basic research application in avian species, since it is difficult to investigate germline development, or germ cell differentiation because of a lack of germ cell-specific markers, transgenic lines expressing reporter genes encoding green fluorescent protein (GFP) or DsRed, controlled by germ cell-specific promoters including those of the vasa, dazl, and ciwi genes, will serve as invaluable tools in the study of avian germ cells. In addition, transgenic poultry are expected to contribute to industrial-scale production of valuable highquality industrial biomaterials. As commercial poultry lines lay more than 340 eggs per year, such eggs can be utilized as animal bioreactors for bioactive protein production.

In contrast to overexpression, knock-down and complete deletion of specific gene were also available through RNAi knock-down and gene targeting, respectively. Recently, state-of-the-art gene-knockout techniques using programmable genome editing technology have been developed to aid in genomic modification. These techniques employ ZFN (Zinc-Finger Nuclease), TALEN (Transcription ActivatorLike Effector Nuclease), and CRISPR-Cas9 (Clustered Regularly Interspaced Short Palindromic Repeats-Cas9). In future, these advanced technologies will be applied in the poultry industry and to further poultry science (Figure 1). ZFN constructs contain zinc-finger DNA-binding domains and engineered FokI endonucleases $[69,70]$. The DNA-binding domains in ZFNs generally contain three-to-six individual zinc-finger repeats, each of which specifically recognizes three nucleotides. The other component of a ZFN is the catalytic domain of a DNA endonuclease derived from the FokI restriction enzyme $[69,70]$. TALEN is a fusion protein of a TAL effector region recognizing a DNA-binding domain, and a DNA cleavage domain of a nuclease [71,72]. TALENs function as heterodimers containing DNA-binding domains that are highly sequence-specific. Basically, a TALEN contains a highly conserved central structure with repeat units of 33-35 amino acids; two variable amino acids at positions 12 and 13 play critical roles in recognition of specific DNA sequences. Two residues, termed Repeat-Variable Di-residues (RVDs), are strongly associated with recognition of specific nucleotides [71,72]. Each RVD can recognize a single nucleotide in a DNA sequence, and a DNAbinding domain that contains an RVD can recognize a stretch of 15-30 nucleotides and is thus capable of binding to a specific locus with very 
Citation: Park TS, Lee HC, Rengaraj D, Han JY (2014) Germ Cell, Stem Cell, and Genomic Modification in Birds. J Stem Cell Res Ther 4: 201. doi:10.4172/2157-7633.1000201

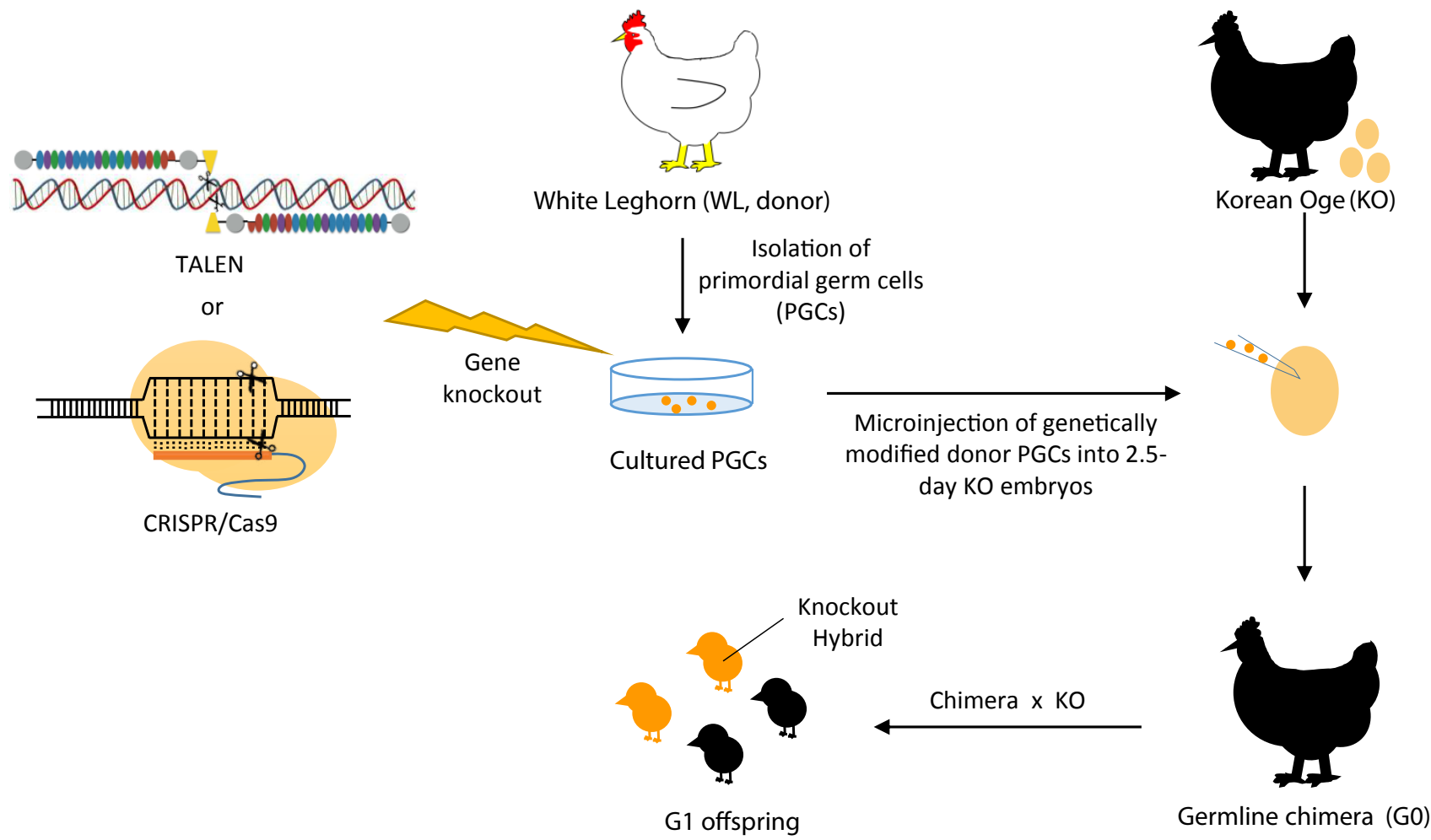

Figure 1: Schematic diagram of genomic editing for avian species with TALENs or CRISPR-Cas9. After genetic modification and gene knockout in cultured PGCs using TALENs or CRISPR-Cas9, the donor PGCs are transplanted into the blood vessel of recipient embryos. Germline chimeras can produce the knockout mutant offspring derived from the transplanted donor PGCs. White leghorn (WL) has a dominant pigmentation inhibitor and Korean Oge chicken (KOC) has a recessive pigmentation inhibitor. The white hybrid chicks from the donor WL PGCs can be distinguished from KOC progenies only by the feather color.

high specificity. Thus, a TALEN can bind to a specific target sequence in the genome and subsequently cleave the target, causing a frameshift mutation. Similarly, CRISPR recognizes target DNA sequences via an RNA-guided binding process, and the Cas9 nuclease next removes (and thus disrupts) the target site [73-75]. Using these technologies, "genetically modified but non-transgenic" poultry may be generated without any risk of transgene contamination because the transferred TALEN and CRISPR transgenes effectively disrupt specific target genes but, after disruption, are degraded and removed from transfected cells. Genetically modified knockout chickens produced using these technical platforms would be similar to naturally mutated strains selected over a long breeding period. When the myostatin gene (which inhibits muscle growth) is disrupted using these systems, such myostatin-knockout chickens would be expected to grow muscle (meat) considerably more rapidly than before. Such chickens would be analogous to Belgium blue cattle, which are double-muscled but not transgenic. No poultry line mutant in the myostatin-encoding gene has yet been reported, but use of the TALEN and CRISPR technical platforms could generate novel strains within a very short period, compared to that of a conventional breeding procedure. Other industrial uses such as modification of egg white composition and allergy-reducing egg production by these stateof-the-art gene-knockout techniques would be applicable in the near future.

\section{Conclusion}

Germ cell characterization and genomic editing in poultry will serve as powerful tools in development of commercial applications and to further basic research. Additionally, use of advanced technologies such as TALEN and CRISPR-Cas9 will in the near future allow genetically modified poultry to be developed rapidly.

\section{Acknwledgement}

This work was supported by a grant from the Next-Generation BioGreen 21 Program (No.PJ008142012014), Rural Development Administration and by Basic Science Research Program through the National Research Foundation of Korea (NRF) funded by the Ministry of Education (2012R1A1A2039004).

\section{References}

1. Ginsburg M, Hochman J, Eyal-Giladi H (1989) Immunohistochemical analysis of the segregation process of the quail germ cell lineage. Int J Dev Biol 33(3): 389-395.[PubMed]

2. Meyer DB (1964) The Migration of Primordial Germ Cells in the Chick Embryo Dev Biol 10: 154-190.[PubMed]

3. Karagenc L, Cinnamon Y, Ginsburg M, Petitte JN (1996) Origin of primordia germ cells in the prestreak chick embryo. Dev Genet 19(4): 290-301.[PubMed]

4. Nieuwkoop PD, Sutasurya LA (1979) Primordial germ cells in the chordates: embryogenesis and phylogenesis. Cambridge Eng; New York: Cambridge University Press.

5. Fujimoto T, Ukeshima A, Kiyofuji R (1976) The origin, migration and morphology of the primordial germ cells in the chick embryo. Anat Rec 185(2): 139-145. [PubMed]

6. Richardson BE, Lehmann R (2010) Mechanisms guiding primordial germ cell migration: strategies from different organisms. Nat Rev Mol Cell Biol 11(1): 37-49.[PubMed]

7. Han JY, Park TS, Kim JN, Kim MA, Lim D, et al. (2006) Gene expression profiling of chicken primordial germ cell ESTs. BMC genomics 7: 220.[PubMed]

8. Kim H, Lim D, Han BK, Sung S, Jeon M, et al. (2006) ChickGCE: a novel germ cell EST database for studying the early developmental stage in chickens. Genomics 88: 252-257.[PubMed] 
Citation: Park TS, Lee HC, Rengaraj D, Han JY (2014) Germ Cell, Stem Cell, and Genomic Modification in Birds. J Stem Cell Res Ther 4: 201. doi:10.4172/2157-7633.1000201

9. Lee SI, Lee BR, Hwang YS, Lee HC, Rengaraj D, et al. (2011) MicroRNAmediated posttranscriptional regulation is required for maintaining undifferentiated properties of blastoderm and primordial germ cells in chickens. Proc Natl Acad Sci U S A 108(26): 10426-10431.[PubMed]

10. Resnick JL, Bixler LS, Cheng, Land Donovan, PJ (1992) Long-term proliferation of mouse primordial germ cells in culture. Nature 359(6395): 550-551.[PubMed]

11. Stewart CL, Gadi, land Bhatt $H$ (1994) Stem cells from primordial germ cells can reenter the germ line. Dev Biol 161(2): 626-628.[PubMed]

12. Park TS, Han JY (2000) Derivation and characterization of pluripotent embryonic germ cells in chicken. Mol Reprod Dev 56(4): 475-482.[PubMed]

13. Park TS, Hong YH, Kwon SC, Lim, JM, Han JY (2003) Birth of germline chimeras by transfer of chicken embryonic germ (EG) cells into recipient embryos. Mol Reprod Dev 65(4): 389-395.[PubMed]

14. Cho, JW, Kim S, Kim TM, Kim, YM, Seo HW, et al. (2010) Basic fibroblast growth factor activates MEK/ERK cell signaling pathway and stimulates the proliferation of chicken primordial germ cells. PLoS one 5(9): e12968.[PubMed]

15. Macdonald J, Taylor L, Sherman A, Kawakami K, Takahashi Y, et al. (2012) Efficient genetic modification and germ-line transmission of primordial germ cells using piggyBac and Tol2 transposons. Proc Natl Acad Sci U S A 109(23): E1466-1472.[PubMed]

16. Park TS, Han JY (2012) piggyBac transposition into primordial germ cells is an efficient tool for transgenesis in chickens. Proc Natl Acad Sci U S A 109(24): 9337-9341.[PubMed]

17. Zhu L, van de Lavoir MC, Albanese J, Beenhouwer DO, Cardarelli PM, et al. (2006) Production of human monoclonal antibody in eggs of chimeric chickens. Nat Biotechnol 23(9): 1159-1169.[PubMed]

18. Kang SJ, Choi JW, Kim SY, Park KJ, Kim TM, et al. (2008) Reproduction of wild birds via interspecies germ cell transplantation. Biol Reprod 79(5): 931937.[PubMed]

19. Kang SJ, Sohn SH, Kang KS, Lee HC, Lee SK, et al. (2011) Molecular and biological aspects of early germ cell development in interspecies hybrids between chickens and pheasants. Theriogenology 75(4): 696-706.[PubMed]

20. Liu C, Khazanehdari KA, Baskar V, Saleem S, Kinne J, et al. (2012) Production of chicken progeny (Gallus gallus domesticus) from interspecies germline chimeric duck (Anas domesticus) by primordial germ cell transfer. Biol Reprod 86(4): 101.[PubMed]

21. Park TS, Han JY (2013) Conservation of migration and differentiation circuits in primordial germ cells between avian species. J Reprod Dev 59(3): 252-257. [PubMed]

22. Wernery U, Liu C, Baskar V, Guerineche Z, Khazanehdari KA, et al. (2010) Primordial germ cell-mediated chimera technology produces viable pure-line Houbara bustard offspring: potential for repopulating an endangered species. PLoS one 5(12): e15824.[PubMed]

23. Extavour CG, Akam M (2003) Mechanisms of germ cell specification across the metazoans: epigenesis and preformation. Development 130(24): 5869-5884. [PubMed]

24. Ephrussi A, Lehmann R (1992) Induction of Germ-cell Formation by Oskar. Nature 358(6385): 387-392.[PubMed]

25. Ikenishi K, Kotani M, Tanabe K (1974) Ultrastructural Changes Associated with Uv Irradiation in Germinal Plasm of Xenopus-Laevis. Dev Biol 36(1): 155-168. [PubMed]

26. Hayashi K, de Sousa Lopes SM, Surani, MA (2007) Germ cell specification in mice. Science 316(5823): 394-396.[PubMed]

27. Swift CH (1914) Origin and early history of the primordial germ-cells in the chick. Baltimore.

28. Eyal-Giladi H, Kochav S (1976) From cleavage to primitive streak formation: a complementary normal table and a new look at the first stages of the development of the chicken. I. General morphology. Dev Biol 49:321-337.

29. Naito M, Sano A, Matsubara Y, Harumi T, Tagami T, et al. (2001) Localization of primordial germ cells or their precursors in stage $X$ blastoderm of chickens and their ability to differentiate into functional gametes in opposite-sex recipient gonads. Reproduction 121(4): 547-552.[PubMed]

30. Tsunekawa N, Naito M, Sakai Y, Nishida T, Noce T (2000) Isolation of chicken vasa homolog gene and tracing the origin of primordial germ cells. Development 127(12): 2741-2750.[PubMed]
31. Hay B Jan LY, Jan YN (1988) A Protein-Component of Drosophila Polar Granules Is Encoded by Vasa and Has Extensive Sequence Similarity to Atpdependent Helicases. Cell 55(4): 577-587.[PubMed]

32. Knaut H, Pelegri F, Bohmann K, Schwarz H, Nusslein-Volhard C (2000) Zebrafish vasa RNA but not its protein is a component of the germ plasm and segregates asymmetrically prior to germline specification. J Cell Biol 149(4): 875-888.[PubMed]

33. Lavial F, Acloque H, Bertocchini F, Macleod DJ, Boast S, et al. (2007) The Oct4 homologue PouV and Nanog regulate pluripotency in chicken embryonic stem cells. Development 134(19): 3549-3563.[PubMed]

34. Motono M, Ohashi T, Nishijima K, lijima S (2008) Analysis of chicken primordia germ cells. Cytotechnology 57(2): 199-205.[PubMed]

35. Aramaki S, Sato F, Kato T, Soh T, Kato Y, et al. (2007) Molecular cloning and expression of dead end homologue in chicken primordial germ cells. Cell Tissue Res 330(1): 45-52.[PubMed]

36. Aramaki S, Kubota K, Soh T, Yamauchi N, Hattori MA (2009) Chicken dead end homologue protein is a nucleoprotein of germ cells including primordial germ cells. J Reprod 55(2): 214-218.[PubMed]

37. Rengaraj D, Zheng YH, Kang KS, Park KJ, Lee BR, et al. (2010) Conserved expression pattern of chicken DAZL in primordial germ cells and germ-line cells. Theriogenology 74(5): 765-776.[PubMed]

38. Jung JG, Kim DK, Park TS, Lee SD, Lim JM, et al. (2005) Development of nove markers for the characterization of chicken primordial germ cells. Stem Cells 23(5): 689-698.[PubMed]

39. Kim JN, Lee YM, Park TS, Jung JG, Cho BW, et al. (2005) Detection and characterization of primordial germ cells in pheasant (Phasianus colchicus) embryos. Theriogenology 63(4):1038-1049.[PubMed]

40. Stebler J, Spieler D, Slanchev K, Molyneaux KA, Richter U, et al. (2004) Primordial germ cell migration in the chick and mouse embryo: the role of the chemokine SDF-1/CXCL12. Dev Biol 272(2): 351-361.[PubMed]

41. Li E, Beard C, Jaenisch R (1993) Role for DNA methylation in genomic imprinting. Nature 366(6453): 362-365.[PubMed]

42. Okano M, Bell DW, Haber DA, Li E (1999) DNA methyltransferases Dnmt3a and Dnmt3b are essential for de novo methylation and mammalian development. Cell 99(3): 247-257.[PubMed]

43. Kimura H, Shiota K (2003) Methyl-CpG-binding protein, MeCP2, is a target molecule for maintenance DNA methyltransferase, Dnmt1. J Biol Chem 278(7): 4806-4812.[PubMed]

44. Jiao F, Wang X, Yan Z, Liu C, Yue Z, et al. (2013) Effect of dynamic DNA methylation and histone acetylation on $\mathrm{CPouV}$ expression in differentiation of chick embryonic germ cells. Stem Cells Dev 22(20): 2725-2735.[PubMed]

45. Yen RW, Vertino PM, Nelkin BD, Yu JJ, el-Deiry W, et al. (1992) Isolation and characterization of the cDNA encoding human DNA methyltransferase. Nucleic Acids Res 20(9): 2287-2291.[PubMed]

46. Rengaraj D, Lee BR, Lee SI, Seo HW, Han JY (2011) Expression patterns and miRNA regulation of DNA methyltransferases in chicken primordial germ cells. PLoS One2011 6(5): e19524.[PubMed]

47. Jang HJ, Seo HW, Lee BR, Yoo M, Womack JE, et al. (2013) Gene expression and DNA methylation status of chicken primordial germ cells. Mol Biotechno 54(2): 177-186.[PubMed]

48. Nakamura Y, Yamamoto Y, Usui F, Mushika T, Ono T, et al. (2007) Migration and proliferation of primordial germ cells in the early chicken embryo. Poult Sci 86(10): 2182-293.[PubMed]

49. Smith CA, Roeszler KN, Bowles J, Koopman P, Sinclair AH (2008) Onset of meiosis in the chicken embryo; evidence of a role for retinoic acid. BMC Dev Biol 8: 85.[PubMed]

50. Zheng YH, Rengaraj D, Choi JW, Park KJ, Lee SI, et al. (2009) Expression pattern of meiosis-associated SYCP family members during germline development in chickens. Reproduction 138(3): 483-492.[PubMed]

51. Kirby JD, Froman DP (2000) Reproduction in male birds. In Avian Physiology ( $5^{\text {th }}$ edn) WhittowSan Diego: Academic Press.

52. Bartel DP (2004) MicroRNAs: genomics, biogenesis, mechanism, and function Cell 116(2): 281-297.[PubMed]

53. Garzon R, Pichiorri F, Palumbo T, Iuliano R, Cimmino A, et al. (2006) MicroRNA 
Citation: Park TS, Lee HC, Rengaraj D, Han JY (2014) Germ Cell, Stem Cell, and Genomic Modification in Birds. J Stem Cell Res Ther 4: 201. doi:10.4172/2157-7633.1000201

fingerprints during human megakaryocytopoiesis. Proc Natl Acad Sci U S A 103(13): 5078-5083.[PubMed]

54. Bartel DP (2009) MicroRNAs: target recognition and regulatory functions. Cell 136(2): 215-233.[PubMed]

55. Sun W, Julie Li YS, Huang HD, Shyy JY, Chien S (2010) microRNA: a maste regulator of cellular processes for bioengineering systems. Annu Rev Biomed Eng 12: 1-27.[PubMed]

56. Foshay KM, Gallicano GI (2009) miR-17 family miRNAs are expressed during early mammalian development and regulate stem cell differentiation. Dev Biol 326(2): 431-443.[PubMed]

57. Wang $X(2008)$ miRDB: a microRNA target prediction and functional annotation database with a wiki interface. RNA 14(6): 1012-1017.[PubMed]

58. Shao P, Zhou H, Xiao ZD, He JH, Huang MB, et al. (2008) Identification of novel chicken microRNAs and analysis of their genomic organization. Gene 418(1-2): 34-40.[PubMed]

59. Smith CA, Roeszler KN, Ohnesorg T, Cummins DM, Farlie PG, et al. (2009) The avian Z-linked gene DMRT1 is required for male sex determination in the chicken. Nature 461(7261): 267-271.[PubMed]

60. Bouhallier F, Allioli N, Lavial F, Chalmel F, Perrard MH, et al. (2010) Role of miR-34c microRNA in the late steps of spermatogenesis. RNA 16(4): 720-731. [PubMed]

61. Rengaraj D, Park TS, Lee SI, Lee BR, Han BK, et al. (2013) Regulation of glucose phosphate isomerase by the 3'UTR-specific miRNAs miR-302b and miR-17-5p in chicken primordial germ cells. Biol Reprod 89(2): 33.[PubMed]

62. Shao P, Liao JY, Guan DG, Yang JH, Zheng LL, et al. (2012) Drastic expression change of transposon-derived piRNA-like RNAs and microRNAs in early stages of chicken embryos implies a role in gastrulation. RNA Biol 9(2): 212-227.[PubMed]

63. Jung $\mathrm{CH}$, Hansen MA, Makunin IV, Korbie DJ, Mattick JS (2010) Identification of novel non-coding RNAs using profiles of short sequence reads from nextgeneration sequencing data. BMC Genomics 11(1): 77.[PubMed]

64. Morozova O, Marra MA (2008) Applications of next-generation sequencing technologies in functional genomics. Genomics 92(5): 255-264.[PubMed]
65. Lim SL, Tsend-Ayush E, Kortschak RD, Jacob R, Ricciardelli C, et al. (2013) Conservation and Expression of piRNA Pathway Genes in Male and Female Adult Gonads of Amniotes. Biol Reprod 89(6): 136.[PubMed]

66. Kim TH, Yun TW, Rengaraj D, Lee SI, Lim SM, et al. (2012) Conserved functional characteristics of the PIWI family members in chicken germ cell lineage. Theriogenology 78(9): 1948-1959.[PubMed]

67. Palmiter RD, Brinster RL, Hammer RE, Trumbauer ME, Rosenfeld MG, et al (1982) Dramatic growth of mice that develop from eggs microinjected with metallothionein-growth hormone fusion genes. Nature 300(5893): 611-615. [PubMed]

68. Park TS, Kang KS, Han JY (2013) Current genomic editing approaches in avian transgenesis. Gen Comp Endocrinol 190: 144-148.[PubMed]

69. Carbery ID, Ji D, Harrington A, Brown V, Weinstein EJ, et al. (2010) Targeted genome modification in mice using zinc-finger nucleases. Genetics 186(2): 451-459.[PubMed]

70. Meyer M, de Angelis MH, Wurst W, Kühn R (2010) Gene targeting by homologous recombination in mouse zygotes mediated by zinc-finger nucleases. Proc Natl Acad Sci U S A 107: 15022-15026.[PubMed]

71. Boch J, Scholze H, Schornack S, Landgraf A, Hahn S, et al. (2009) Breaking the code of DNA binding specificity of TAL-type III effectors. Science 326(5959): 1509-1512.[PubMed]

72. Moscou MJ, Bogdanove AJ (2009) A simple cipher governs DNA recognition by TAL effectors. Science 326(5959): 1501.[PubMed]

73. Jinek M, Chylinski K, Fonfara I, Hauer M, Doudna JA, et al. (2012) Programmable dual-RNA-guided DNA endonuclease in adaptive bacterial immunity. Science 337(6096): 816-821.[PubMed]

74. Cong L, Ran FA, Cox D, Lin S, Barretto R, et al. (2013) Multiplex genome engineering using CRISPR/Cas systems. Science 339(6121): 819-823. [PubMed]

75. Mali P, Yang L, Esvelt KM, Aach J, Guell M, et al. (2013) RNA-guided human genome engineering via Cas9. Science 339(6121): 823-826.[PubMed] 